\title{
PENGEMBANGAN LEMBAR KEGIATAN PESERTA DIDIK (LKPD) PADA MATERI POKOK EUBACTERIA BERBASIS
} PENDEKATAN ILMIAH

\author{
Almira Velda Harahap ${ }^{{ }_{1}}$, Zulkifli Simatupang ${ }^{2}$, Eni Susanti ${ }^{3}$ \\ ${ }^{1,2}$ Program Studi Pendidikan Biologi, FMIPA, Universitas Negeri Medan, Jl. Willem Iskandar Psr. V Medan Estate Fax. (061) \\ 614002-613319, Medan, Indonesia, 20221 \\ ${ }^{3}$ SMA Negeri 4 Medan, Jalan Gelas No. 12, Kelurahan Sei Putih Tengah Medan Petisah, Medan, Indonesia, 20118, \\ ${ }^{*}$ E-mail : almiraveldaharahap@gmail.com
}

\begin{abstract}
ABSTRAK
Penelitian ini bertujuan untuk mengetahui penilaian LPKD pada materi pokok Eubacteria berbasis pendekatan ilmiah oleh ahli dan praktisi. Penelitian menggunakan desain pengembangan instruksional model 4-D, dibatasi hingga tahap develop. Prosedur pengembangannya dimulai dari tahap pertama pendefinisian yang meliputi analisis KI, KD dan indikator kompetensi, kondisi peserta didik. Tahap kedua perancangan, yang meliputi pengumpulan data berupa silabus, merumuskan tujuan khusus yang ingin dicapai, menyusun kerangka penyajian. Tahap ketiga adalah pengembangan meliputi validasi oleh ahli materi dan pendidikan, tanggapan guru biologi, dan tanggapan peserta didik pada uji kelompok kecil. Produk yang dihasilkan berupa lembar kegiatan peserta didik (LKPD) pada materi Eubacteria berbasis pendekatan ilmiah. Hasil penilaian oleh ahli materi menunjukkan rata-rata 93,75\% kriteria sangat baik, dan ahli pendidikan 92\% kriteria sangat baik. Hasil tanggapan guru biologi mendapat hasil $80,21 \%$ ktiteria baik. Hasil tanggapan peserta didik pada uji kelompok kecil mendappat hasil $92 \%$ kriteria sangat baik.
\end{abstract}

Kata Kunci : Lembar Kegiatan Peserta Didik, Pendekatan Ilmiah, Pengembangan

\section{ABSTRACT}

This research aims to know the value of a student worksheet Eubacteria based on scientific approach by experts and practitioners. This research has develop with 4-D models that has been modified consist three stages. The first stages is define, which include analysis of main competency, basic competencies, indicators of competence, and condition of student. The second stage is the design, which consist of data collection in the form of the syllabus, to formulate specific objectives to be achieved, preparing presentation framework. The third stage is develop, which consist of validation by matter expert and education expert, biology teacher responses, and student responses in a small group. The product produced in the form of worksheets Eubacteria based on scientific approach. Student worksheet complied and considered feasible by validation team. Results of the assesment team of matter expert showed an average $93,75 \%$ categorized a very good and education expert $92 \%$ categorized as very good. Result responses biology teacher got the result $80,21 \%$ categorized good. Result of student responses of the small group got $92 \%$ categorized as very good.

Keywords : Development, Scientific Approach, Worksheet

\section{PENDAHULUAN}

Kurikulum 2013 mengamanatkan esensi pendekatan ilmiah (scientific approach) dalam pembelajaran. Pendekatan ilmiah dalam pembelajaran sebagaimana dimaksud dijalankan dengan tahapan belajar melalui mengamati, menanya, mengumpulkan informasi, mengasosiasi, dan mengkomunikasikan untuk semua mata pelajaran (Kemendikbud 2013). Dalam penerapan pendekatan ilmiah membutuhkan pengembangan bahan ajar (learning material) dan perlengkapan belajar (learning tools) yang dapat dijadikan pedoman dalam mengimplementasikannya di kelas sehingga siswa lebih aktif terlibat dalam proses pembelajaran. Dalam hal ini, guru dituntut untuk lebih kreatif agar siswanya lebih aktif dan terlibat dalam proses pembelajaran.

Tetapi dalam penerapannya masih ditemukan beberapa kendala sebagaimana yang dilaporkan (Mei 2014), beberapa kendala yang dihadapi sebagai berikut, sulitnya menarik minat siswa untuk bertanya, kurangnya waktu, rumitnya persiapan, kelas cenderung sulit dikendalikan, dan siswa banyak yang terlambat mengumpulkan tugas. 
JURNAL PELITA PENDIDIKAN VOL. 5 NO. 3

Harahap, AV., Simatupang, Z., Susanti, E.

Halaman : 330- 338

Lebih lanjut dalam hal ini (Surachman et al, 2014) mengemukakan bahwa penerapan pendekatan ilmiah belum optimal. Dan hasil penelitian (Utari 2017) melaporkan bahwa pembelajaran yang berlangsung pada sekolah belum dapat menerapkan pendekatan ilmiah secara optimal. Pendidik masih belum optimal dalam memfasilitasi pembelajaran di dalam kelas dalam setiap kegiatannya. Hasil wawancara dengan guru Biologi di beberapa sekolah ditemukan bahwa selama ini guru hanya memanfaatkan bahan ajar yang dikembangkan orang lain (penerbit) dalam bentuk buku teks dan guru juga tidak menyediakan lembar kegiatan peserta didik untuk kegiatan praktikum dalam mempelajari materi Archaebacteria dan Eubacteria. Guru hanya menyediakan lembar kerja siswa yang berisi ringkasan materi dan latihan soal.

Hasil studi pendahuluan yang dilakukan oleh penulis (survey tidak dipublikasikan) terhadap lima buah buku pelajaran Biologi SMA/MA Kelas $X$ (Irnaningtyas 2013; Karmana 2013; Nurhayati 2013; Pitoyo 2013; Prawirohartono 2013), yang beredar di kota Medan, ditemukan bahwa kelima buku tersebut memuat beberapa kegiatan praktikum untuk materi pokok Archaebacteria dan Eubacteria tetapi tidak memuat format lembar hasil pengamatan dan tidak disusun sesuai dengan langkah pendekatan ilmiah

Berdasarkan fenomena dan masalah yang diuraikan di atas, maka perlu dilakukan peningkatan kualitas pembelajaran dan pengoptimalan efektivitas proses pembelajaran. Salah satunya dengan melakukan pengembangan lembar kegiatan peserta didik (LKPD) pada materi Eubacteria berbasis pendekatan ilmiah.

\section{METODE PENELITIAN}

Persiapan penelitian dimulai sejak bulan Desember 2016 - April 2017. Pengembangan produk LKPD dimulai sejak bulan April 2016 - Mei 2016 dan uji coba produk untuk mengetahui kelayakan produk yang dihasilkan dilaksanakan pada bulan Juni 2017. Pelaksanaan uji coba untuk menilai kelayakan produk pengembangan LKPD yang dihasilkan di SMA Negeri 4 Medan yang beralamat di Jalan Gelas No. 12, Kelurahan Sei Putih Tengah, Kecamatan Medan Petisah, Kota Medan, Provinsi Sumatera Utara.
pISSN : 2338 - 3003

elSSN : 2502 - 3217
Model pengembangan yang digunakan mengacu pada model 4-D yang disarankan oleh Thiangarajan et al (1974). Model pengembangan ini terdiri dari 4 tahap, yaitu pendefinisian (define), perancangan (design), pengembangan (develop), dan penyebaran (disseminate) (Trianto 2010). Namun dalam penelitian ini hanya terbatas sampai tahap pengembangan (develop). Pada tahap pendefinisian dilakukan langkah sebagai berikut: (1) Melakukan analisis kurikulum, analisis kebutuhan dan analisis masalah yang menjadi dasar pengembangan LKPD; (2) Melakukan analisis siswa sebagai objek pengguna LKPD; (3) Analisis tugas; (4) Analisis konsep; (5) Analisis tujuan pengembangan LKPD . Pada tahap perancangan dilakukan dengan merancang perangkat pembelajaran, sehingga diperoleh prototipe LKPD. Pada tahap pengembangan dilakukan penilaian para ahli dan uji coba kelompok kecil.

\section{HASIL PENELITIAN}

Hasil penelitian ini mendeskripsikan tentang (1) proses pengembangan LKPD dan (2) hasil penilaian kelayakan produk yang dikembangkan dan divalidasi sesuai aspek materi maupun pembelajaran, penilaian dan tanggapan oleh guru dan peserta didik.

\section{Proses Pengembangan LKPD}

Pengembangan LKPD diawali dengan melakukan analisis kebutuhan peserta didik dan melakukan wawancara terhadap tiga guru mata pelajaran biologi. Dalam hal ini peneliti menemukan beberapa fakta yaitu; peserta didik jarang sekali diberikan praktikum pada saat pembelajaran materi pokok Eubacteria, materi pembelajaran selalu diberikan guru dengan ceramah, bahan ajar untuk kegiatan pembelajaran biologi di kelas berupa buku teks dari penerbit. Pada tahap analisis peserta didik bertujuan untuk menelaah karakteristik siswa SMA sebagai objek penggunaan LKPD yang dikembangkan. Siswa SMA pada umumnya sudah mulai berfikir abstrak meliputi kemampuan berfikir, kemampuan untuk mengintegrasikan pengetahuan sebelumnya dan struktur berfikir yang baru. Atas dasar karakteristik tersebut maka dapat disimpulkan bahwa pada dasarnya belajar dengan melibatkan objek 
sebenarnya secara langsung akan lebih mudah ditangkap atau diserap dan lebih tahan lama dalam ingatan siswa. Hal tersebut dapat diperoleh oleh peserta didik dengan melakukan kegiatan praktikum. Pada tahap analisis tugas bertujuan mengidentifikasi keterampilan utama yang dibutuhkan dan menguraikannya ke dalam keterampilan-keterampilan yang lebih khusus. Analisis dilakukan terhadap kompetensi inti (KI) dan kompetensi dasar (KD) sebagai acuan pengembangan LKPD. Selanjutnya dilakukan analisis konsep untuk mengetahui konsep penting yang akan diajarkan berdasarkan KD yang akan dikembangkan dan melakukan perumusan tujuan pembelajaran.

Perancangan pengembangan struktur LKPD disesuaikan dengan struktur LKS menurut Depdiknas (2006) yaitu struktur yang baik mencakup judul, petunjuk belajar, kompetensi yang dicapai, informasi pendukung, tugas-tugas dan langkah kerja. Pengembangan LKPD (LKPD) berbasis pendekatan ilmiah dimulai dari tahap perencanaan yang terdiri dari perancangan: (1) format LKPD (2) komponen penyajian; (3) materi; (4) soal-soal latihan.
Tahap pengembangan dilakukan dengan penilaian kepada ahli materi dan ahli pendidikan sebagai validator dan tiga guru biologi SMA sebagai responden pada penilaian draft produk yang sudah divalidasikan kepada ahli. Hasil dari validasi akan mempermudah untuk melakukan revisi pada draf produk. Kemudian dilakukan uji coba lapangan pada kelompok kecil untuk memperoleh tanggapan peserta didik terhadap LKPD yang dikembangkan.

\section{Deskripsi Hasil Validasi}

Berdasarkan hasil validasi ahli materi, validator ahli materi memberikan skor total 42 untuk aspek penyajian materi dan skor total 8 untuk aspek kebahasaan. Berdasarkan hasil validasi tersebut, persentase aspek kelayakan penyajian materi sebesar $87,5 \%$ dengan kriteria sangat baik dan persentase aspek kebahasaan sebesar 100\% dengan kriteria sangat baik (Tabel 1). Berdasarkan hasil validasi ahli materi, segi aspek kelayakan penyajian materi dan kebahasaan terhadap produk LKPD diperoleh rata-rata persentase 93,75\%. Sehingga produk LKPD yang telah dikembangkan termasuk dalam kriteria sangat baik (Tabel 2).

Tabel 1. Hasil Validasi Materi

\begin{tabular}{|c|c|c|c|c|}
\hline $\begin{array}{c}\text { Aspek Yang } \\
\text { dinilai }\end{array}$ & Indikator & Skor & Persentase & Keterangan \\
\hline \multirow[t]{12}{*}{$\begin{array}{l}\text { Kelayakan } \\
\text { penyajian materi }\end{array}$} & $\begin{array}{l}\text { 1. Kesesuaian materi pokok dengan } \\
\text { Kompetensi Inti }\end{array}$ & 4 & $100 \%$ & Sangat baik \\
\hline & $\begin{array}{l}\text { 2. Kesesuaian materi pokok dengan } \\
\text { Kompetensi Dasar }\end{array}$ & 4 & $100 \%$ & Sangat baik \\
\hline & 3. Kejelasan penyajian materi & 3 & $75 \%$ & Baik \\
\hline & 4. Kedalaman materi & 3 & $75 \%$ & Baik \\
\hline & 5. Kualitas penjabaran materi & 3 & $75 \%$ & Baik \\
\hline & $\begin{array}{l}\text { 6. Keterkaitan soal latihan dengan } \\
\text { materi }\end{array}$ & 4 & $100 \%$ & Sangat baik \\
\hline & 7. Kualitas LKPD & 4 & $100 \%$ & Sangat baik \\
\hline & $\begin{array}{l}\text { 8. Ketepatan dalam menyajikan } \\
\text { contoh-contoh }\end{array}$ & 3 & $75 \%$ & Baik \\
\hline & 9. Kebenaran konsep & 3 & $75 \%$ & Baik \\
\hline & 10. Kualitas pustaka yang digunakan & 4 & $100 \%$ & Sangat baik \\
\hline & 11. Kemenarikan Ilustrasi & 4 & $100 \%$ & Sangat baik \\
\hline & 12. Kemenarikan Gambar & 3 & $75 \%$ & Baik \\
\hline Rata-rata & & 3,5 & $87,5 \%$ & Sangat Baik \\
\hline \multirow[t]{2}{*}{ Kebahasaan } & 13. Penggunaan bahasa & 4 & $100 \%$ & Sangat baik \\
\hline & 14. Keterbacaan & 4 & $100 \%$ & Sangat baik \\
\hline Rata-rata & & 4 & $100 \%$ & Sangat Baik \\
\hline
\end{tabular}


Tabel 2. Persentase Hasil Validasi Materi

\begin{tabular}{lll}
\hline Aspek yang Dinilai & Persentase Rata-Rata & Keterangan \\
\hline Kelayakan penyajian materi & $87,5 \%$ & Sangat Baik \\
Kebahasaan & $100 \%$ & Sangat Baik \\
\hline Rata-rata & $\mathbf{9 3 , 7 5 \%}$ & Sangat Baik \\
\hline
\end{tabular}

Berdasarkan hasil validasi ahli pendidikan, validator ahli pendidikan memberikan skor total 14 untuk aspek kelayakan isi dan skor total 27 untuk aspek komponen pembelajaran berbasis pendekatan ilmiah. Berdasarkan hasil validasi tersebut, persentase aspek kelayakan isi sebesar 87,5\% dengan kriteria sangat baik dan persentase aspek komponen pembelajaran berbasis pendekatan ilmiah sebesar
96,5\% dengan kriteria sangat baik (Tabel 3). Berdasarkan hasil validasi ahli pendidikan, segi aspek kelayakan isi dan komponen pembelajaran berbasis pendekatan ilmiah terhadap produk LKPD diperoleh rata-rata persentase $92 \%$. Sehingga produk LKPD yang telah dikembangkan termasuk dalam kriteria sangat baik (Tabel 4 ).

Tabel 3. Hasil Validasi Pembelajaran

\begin{tabular}{|c|c|c|c|c|c|}
\hline $\begin{array}{l}\text { Aspek Yang } \\
\text { dinilai }\end{array}$ & \multicolumn{2}{|c|}{ Indikator } & Skor & Persentase & Keterangan \\
\hline \multirow[t]{4}{*}{ Kelayakan Isi } & \multicolumn{2}{|l|}{ 1. Penuangan ide atau gagasan } & 4 & $100 \%$ & Sangat baik \\
\hline & \multicolumn{2}{|l|}{ 2. Desain tampilan (cover) LKPD } & 3 & $75 \%$ & Baik \\
\hline & \multicolumn{2}{|l|}{ 3. Desain penyajian isi } & 4 & $100 \%$ & Sangat baik \\
\hline & \multicolumn{2}{|l|}{ 4. Penyusunan LKPD } & 3 & $75 \%$ & Baik \\
\hline \multicolumn{3}{|l|}{ Rata-rata } & 3,5 & $87,5 \%$ & Sangat Baik \\
\hline \multirow{7}{*}{$\begin{array}{l}\text { Komponen } \\
\text { Pembelajaran } \\
\text { berbasis } \\
\text { pendekatan } \\
\text { ilmiah }\end{array}$} & \multicolumn{2}{|c|}{$\begin{array}{l}\text { 5. Mendorong dan menginspirasi siswa berfikir kritis, } \\
\text { analistis dan tepat dalam mengidentifikasi, } \\
\text { memahami, memecahkan masalah dan } \\
\text { mengaplikasikan materi pembelajaran }\end{array}$} & 4 & $100 \%$ & Sangat baik \\
\hline & \multicolumn{2}{|c|}{$\begin{array}{l}\text { 6. Mendorong dan menginspirasi siswa untuk } \\
\text { mengamati }\end{array}$} & 4 & $100 \%$ & Sangat baik \\
\hline & \multicolumn{2}{|c|}{$\begin{array}{l}\text { 7. Mendorong dan menginspirasi siswa untuk } \\
\text { bertanya }\end{array}$} & 4 & $100 \%$ & Sangat baik \\
\hline & \multicolumn{2}{|c|}{$\begin{array}{l}\text { 8. Mendorong dan menginspirasi siswa untuk } \\
\text { menalar/berasosiasi }\end{array}$} & 3 & $75 \%$ & Baik \\
\hline & \multicolumn{2}{|c|}{$\begin{array}{l}\text { 9. Mendorong dan menginspirasi siswa untuk } \\
\text { berekperimen }\end{array}$} & 4 & $100 \%$ & Sangat baik \\
\hline & \multicolumn{2}{|c|}{$\begin{array}{l}\text { 10. Mendorong dan menginspirasi siswa untuk } \\
\text { menarik sebuah kesimpulan }\end{array}$} & 4 & $100 \%$ & Sangat baik \\
\hline & \multicolumn{2}{|c|}{$\begin{array}{l}\text { 11. Mendorong dan menginspirasi siswa untuk } \\
\text { mengkomunikasikan hasil temuannya }\end{array}$} & 4 & $100 \%$ & Sangat baik \\
\hline \multicolumn{3}{|l|}{ Rata-rata } & 3,86 & $96,5 \%$ & Sangat Baik \\
\hline \multicolumn{4}{|c|}{$\frac{\text { Tabel 4. Persentase Hasil Validasi Pembelajaran }}{\text { Persentase Rata-Rata }}$} & Keterangan & \\
\hline \multirow{2}{*}{\multicolumn{2}{|c|}{$\begin{array}{l}\text { Kelayakan isi } \\
\text { Komponen pembelajaran berbasis pendekatan } \\
\text { ilmiah }\end{array}$}} & $87,5 \%$ & & Sangat Baik & \\
\hline & & $96,5 \%$ & & Sangat Baik & \\
\hline \multicolumn{2}{|l|}{ Rata-rata } & $92 \%$ & & Sangat Baik & \\
\hline
\end{tabular}


Berdasarkan hasil penilaian yang diberikan oleh tiga orang guru biologi terhadap produk LKPD berbasis pendekatan ilmiah diperoleh rata-rata persentase $80,21 \%$ dengan kriteria baik (Tabel 5). Hal ini berarti bahwa LKPD berbasis pendekatan ilmiah pada materi Eubacteria yang telah dikembangkan ini dinyatakan telah layak digunakan dalam pembelajaran biologi di kelas $X$ Sekolah Menengah Atas. Respon peserta didik uji coba kelompok kecil memperoleh skor total 321. Berdasarkan hasil penilaian yang diberikan oleh 25 orang peserta didik terhadap produk LKPD diperoleh persentase 92\% dengan kriteria sangat baik (Tabel 6). Hal ini berarti bahwa LKPD berbasis pendekatan ilmiah pada materi Eubacteria yang telah dikembangkan ini dinyatakan telah layak digunakan dalam pembelajaran biologi di kelas X Sekolah Menengah Atas.

Tabel 5. Hasil Penilaian Guru Biologi Terhadap LKPD pada materi pokok Eubacteria berbasis Pendekatan IImiah

\begin{tabular}{|c|c|c|c|c|c|c|c|}
\hline \multirow{2}{*}{$\begin{array}{c}\text { Aspek Yang } \\
\text { dinilai }\end{array}$} & \multirow{2}{*}{ Indikator } & \multicolumn{3}{|c|}{ Responden } & \multirow{2}{*}{ Jlh Skor } & \multirow{2}{*}{$\begin{array}{c}\text { Persentase } \\
\text { Rata-Rata }\end{array}$} & \multirow{2}{*}{ Ket } \\
\hline & & 1 & 2 & 3 & & & \\
\hline Tampilan & 1. Desain tampilan (cover) LKPD & 3 & 3 & 3 & 9 & $75 \%$ & Baik \\
\hline \multirow[t]{2}{*}{ LKPD } & 2. Desain penyajian isi & 3 & 3 & 3 & 9 & $75 \%$ & Baik \\
\hline & 3. Penyusunan LKPD & 4 & 3 & 4 & 11 & $91,67 \%$ & $\begin{array}{l}\text { Sangat } \\
\text { baik }\end{array}$ \\
\hline \multirow[t]{4}{*}{ Kelayakan Isi } & $\begin{array}{l}\text { 4. Kesesuaian materi pokok dengan } \\
\text { Kompetensi Inti }\end{array}$ & 3 & 3 & 3 & 9 & $75 \%$ & Baik \\
\hline & $\begin{array}{l}\text { 5. Kesesuaian materi pokok dengan } \\
\text { Kompetensi Dasar }\end{array}$ & 3 & 3 & 3 & 9 & $75 \%$ & Baik \\
\hline & 6. Kualitas penjabaran materi & 3 & 3 & 3 & 9 & $75 \%$ & Baik \\
\hline & $\begin{array}{l}\text { 7. Keterkaitan soal latihan dengan } \\
\text { materi }\end{array}$ & 3 & 3 & 3 & 9 & $75 \%$ & Baik \\
\hline \multirow{7}{*}{$\begin{array}{l}\text { Komponen } \\
\text { Pembelajaran } \\
\text { berbasis } \\
\text { pendekatan } \\
\text { ilmiah }\end{array}$} & $\begin{array}{l}\text { 8. Memotivasi siswa berfikir kritis, } \\
\text { analistis dan tepat dalam } \\
\text { mengidentifikasi dan memahami } \\
\text { materi pembelajaran }\end{array}$ & 3 & 3 & 3 & 9 & $75 \%$ & Baik \\
\hline & $\begin{array}{l}\text { 9. Memotivasi siswa untuk } \\
\text { mengamati }\end{array}$ & 4 & 3 & 4 & 11 & $91,67 \%$ & $\begin{array}{l}\text { Sangat } \\
\text { baik }\end{array}$ \\
\hline & $\begin{array}{l}\text { 10. Memotivasi siswa untuk } \\
\text { bertanya }\end{array}$ & 4 & 3 & 4 & 11 & $91,67 \%$ & $\begin{array}{l}\text { Sangat } \\
\text { baik }\end{array}$ \\
\hline & $\begin{array}{l}\text { 11. Memotivasi siswa untuk } \\
\text { mengumpulkan informasi }\end{array}$ & 3 & 3 & 3 & 9 & $75 \%$ & Baik \\
\hline & $\begin{array}{l}\text { 12. Memotivasi siswa untuk } \\
\text { menalar/berasosiasi }\end{array}$ & 4 & 2 & 4 & 10 & $83,33 \%$ & $\begin{array}{l}\text { Sangat } \\
\text { baik }\end{array}$ \\
\hline & $\begin{array}{l}\text { 13. Memotivasi siswa untuk menarik } \\
\text { sebuah kesimpulan }\end{array}$ & 3 & 3 & 3 & 9 & $75 \%$ & Baik \\
\hline & $\begin{array}{l}\text { 14. Memotivasi siswa untuk } \\
\text { mengkomunikasikan hasil } \\
\text { temuannya }\end{array}$ & 4 & 3 & 4 & 11 & $91,67 \%$ & $\begin{array}{l}\text { Sangat } \\
\text { baik }\end{array}$ \\
\hline \multirow[t]{2}{*}{ Kebahasaan } & 15. Penggunaan Bahasa & 4 & 3 & 4 & 11 & $91,67 \%$ & $\begin{array}{l}\text { Sangat } \\
\text { baik }\end{array}$ \\
\hline & 16. Keterbacaan & 3 & 2 & 3 & 8 & $66,67 \%$ & Baik \\
\hline Rata-rata & & & & & & $80,21 \%$ & Baik \\
\hline
\end{tabular}


Tabel 6. Hasil Penilaian Uji Coba Kelompok Kecil

\begin{tabular}{|c|c|c|c|c|}
\hline $\begin{array}{l}\text { Aspek Yang } \\
\text { Dinilai }\end{array}$ & Instrumen Pengukuran Tanggapan Siswa & Jlh Skor & $\begin{array}{l}\text { Persentase } \\
\text { Rata-Rata }\end{array}$ & Ket \\
\hline \multirow[t]{2}{*}{ Tampilan LKPD } & $\begin{array}{l}\text { Tampilan fisik dari LKPD ini sangat menarik, sehingga saya } \\
\text { tertarik untuk membacanya }\end{array}$ & 25 & $100 \%$ & $\begin{array}{l}\text { Sangat } \\
\text { Baik }\end{array}$ \\
\hline & $\begin{array}{l}\text { Penyajian materi mengundang minat saya untuk } \\
\text { membacanya }\end{array}$ & 25 & $100 \%$ & $\begin{array}{l}\text { Sangat } \\
\text { Baik }\end{array}$ \\
\hline \multirow[t]{6}{*}{ Penyajian LKPD } & Petunjuk yang ada dalam LKPD mudah dimengerti & 23 & $92 \%$ & $\begin{array}{l}\text { Sangat } \\
\text { Baik }\end{array}$ \\
\hline & Peta konsep dapat dipahami dengan jelas & 20 & $80 \%$ & Baik \\
\hline & $\begin{array}{l}\text { Kalimat dalam LKPD ini jelas dengan bahasa baku dan } \\
\text { mudah saya pahami }\end{array}$ & 25 & $100 \%$ & $\begin{array}{l}\text { Sangat } \\
\text { Baik }\end{array}$ \\
\hline & $\begin{array}{l}\text { Gambar ilustrasi penyusunan perangkat eksperimen yang } \\
\text { disajikan pada LKPD ini memudahkan saya memahami } \\
\text { materi }\end{array}$ & 23 & $92 \%$ & $\begin{array}{l}\text { Sangat } \\
\text { Baik }\end{array}$ \\
\hline & Soal-soal yang ada dalam LKPD mudah dipahami & 19 & $76 \%$ & Baik \\
\hline & $\begin{array}{l}\text { LKPD menyediakan ruang yang cukup sehingga saya dapat } \\
\text { menulis atau menggambarkan suatu pemikiran pada LKPD }\end{array}$ & 22 & $88 \%$ & $\begin{array}{l}\text { Sangat } \\
\text { Baik }\end{array}$ \\
\hline \multirow{6}{*}{$\begin{array}{l}\text { Komponen } \\
\text { Pembelajaran } \\
\text { Berbasis } \\
\text { Pendekatan } \\
\text { Ilmiah }\end{array}$} & LKPD memotivasi saya untuk mengamati & 25 & $100 \%$ & $\begin{array}{l}\text { Sangat } \\
\text { Baik }\end{array}$ \\
\hline & LKPD memotivasi saya untuk bertanya & 22 & $88 \%$ & $\begin{array}{l}\text { Sangat } \\
\text { Baik }\end{array}$ \\
\hline & LKPD memotivasi saya untuk mengumpulkan informasi & 23 & $92 \%$ & $\begin{array}{l}\text { Sangat } \\
\text { Baik }\end{array}$ \\
\hline & LKPD memotivasi saya untuk menalar/berasosiasi & 25 & $100 \%$ & $\begin{array}{l}\text { Sangat } \\
\text { Baik }\end{array}$ \\
\hline & LKPD memotivasi saya untuk menarik sebuah kesimpulan & 24 & $96 \%$ & $\begin{array}{l}\text { Sangat } \\
\text { Baik }\end{array}$ \\
\hline & $\begin{array}{l}\text { LKPD memotivasi saya untuk mengkomunikasikan hasil } \\
\text { temuannya }\end{array}$ & 20 & $80 \%$ & Baik \\
\hline Rata-rata & & 22,93 & $92 \%$ & $\begin{array}{l}\text { Sangat } \\
\text { Baik }\end{array}$ \\
\hline
\end{tabular}

\section{PEMBAHASAN}

LKPD berbasis pendekatan ilmiah yang dikembangkan dinilai oleh validator ahli materi dari aspek kelayakan penyajian materi dan keterbacaan. Kelayakan penyajian materi diperoleh persentase $87,5 \%$ dengan kriteria sangat baik. Aspek kelayakan penyajian materi menunjukkan bahwa materi pokok yang terdapat di dalam LKPD sudah sesuai dengan KI dan KD pada Kurikulum 2013. Hal ini dikarenakan dalam penyusunan LKPD mengacu pada tujuan pembelajaran serta uraian materi yang telah disesuaikan dengan kompetensi inti (KI) dan kompetensi datar (KD), sebagaimana halnya persyaratan untuk penyusunan perangkat pembelajaran yang baik. Seperti yang dikemukakan Kariem, et al (2013) bahwa, menyusun sumber belajar harus memperhatikan kurikulum. Menurut Dinas Pendidikan Nasional (2006) bahwa lembar kerja siswa itu salah satunya harus memuat kompetensi dasar, dengan adanya kompetensi dasar sebagai acuan maka akan dapat membantu peserta didik belajar secara terarah.

Kejelasan materi yang ada di dalam LKPD sudah baik artinya materi yang disampaikan secara runtut, hal ini sesuai dengan pendapat Devi dkk (2009) bahwa, materi harus disajikan secara 
JURNAL PELITA PENDIDIKAN VOL. 5 NO. 3

Harahap, AV., Simatupang, Z., Susanti, E.

Halaman : 330-338

sistematis dan logis. LKPD juga sudah memiliki kedalaman materi yang baik yaitu sudah sesuai dengan tingkat pendidikan SMA. Kualitas penjabaran materi dijabarkan dengan baik melalui peta konsep, contoh-contoh yang nyata, menyajikan gambargambar yang sesuai dengan konsep materi, memberikan arti atau definisi dari suatu istilah yang masih bersifat abstrak.

Keterkaitan soal latihan dengan materi juga mendapat penilaian sangat baik, yaitu sesuai dengan materi yang mengacu pada tujuan pembelajaran karena menurut Depdiknas (2004) syarat dan prinsip penyusunan lembar kerja siswa harus menentukan tujuan pembelajaran untuk dimodifikasi ke bentuk pembelajaran dengan lembar kerja siswa. Selain mengacu pada tujuan pembelajaran, kegiatan yang ada di dalam LKPD juga harus memotivasi siswa dalam pembelajaran secara mandiri karena lembar kerja peserta didik itu pada dasarnya berfungsi dalam menyelenggarakan kegiatan belajar mengajar dan sudah menerapkan metode membelajarkan peserta didik secara aktif.

Kemandirian dan keaktifan peserta didik dalam mengerjakan LKPD juga tentunya harus didukung oleh penyajian yang menarik dengan memberikan contoh-contoh gambar yang dapat membantu peserta didik dalam memahami materi, dan tentunya materi diperoleh dari pustaka-pustaka yang dapat dipercaya, LKPD ini menggunakan pustaka-pustaka yang relevab dengan materi.

Selain itu, kualitas gambar yang digunakan LKPD dianggap jelas, menarik, memperjelas penyampaian uraian dan representative untuk penyampaian konsep. Menurut Komalasari (2011) suatu gambar dan foto dapat memberikan gambaran nyata yang menunjukkan objek sesungguhnya, memberikan makna pembelajaran yang lebih hidup dan tepat dibanding dengan kata-kata sehingga merangsang kemampuan berfikir siswa (menganalisis). Dengan demikian perangkat soal akan berpengaruh positif terhadap siswa terutama pada peningkatan motivasi siswa untuk mengerjakan soal. Hal itu juga didukung dengan hasil validasi ahli materi terhadap kemenarikan ilustrasi dan gambar dengan kriteria sangat baik.
pISSN : 2338 - 3003

elSSN : 2502 - 3217

Aspek yang kedua yaitu aspek kebahasaan diperoleh persentase $100 \%$ dengan kategori sangat baik. Aspek kebahasaan memiliki dua komponen yaitu penggunaan bahasa dan keterbacaan. Kedua aspek ini sudah sangat baik karena bahasa yang digunakan sesuai dengan kamus besar bahasa Indonesia dan tingkat perkembangan peserta didik, komunikatif dan interaktif.

LKPD berbasis pendekatan ilmiah yang dinilai oleh validator ahli pendidikan terdiri dari aspek kelayakan penyajian isi dan komponen pembelajaran berbasis pendekatan ilmiah. Aspek kelayakan penyajian isi memilki empat komponen yaitu penuangan ide atau gagasan, desai tampilan (cover) LKPD, desain penyajian isi, dan penyusunan LKPD diperoleh persentase sebesar 87,5\% dengan kriteria sangat baik. Kelayakan penyajian isi dilihat dari penuangan ide atau gagasan termasuk dalam kriteria sangat baik karena disajikan dari yang mudah ke yang sukar dan disajikan dengan menggunakan gambar yang sesuai. Hal ini sesuai dengan pendapat Devi (2009) penyusunan lembar kerja sesuai struktur dari segi tampilan harus memperhatikan minat dan mengajak siswa untuk berpikir seperti dengan menggunakan gambar, grafik, tabel serta instruksi dan pertanyaan harus jelas. Desain tampilan (cover) maupun desain penyajian isi LKPD harus memperhatikan tata letak, pemilihan gambar yang sesuai, pemilihan teks dan pemilihan warna yang menarik sesuai dengan penilaian unsur-unsur yang dikeluarkan oleh BSNP yang salah satunya mengacu pada komponen kegrafikan, keseuaian ukuran font, layout, dan tata letak, desain tampilan dan keterbacaan. Namun, sumber belajar yang baik tidak hanya memperhatikan kualitas penyajian saja tetapi efektif juga dalam memotivasi peserta didik.

Hal-hal yang disajikan dalam LKPD ini juga dapat memotivasi peserta didik yaitu memberikan kegiatan-kegiatan pembelajaran yang sesuai dengan langkah pendekatan ilmiah. Langkah pertama dengan kegiatan mengamati gambar, langkah kedua dengan kegiatan bertanya dan langkah ketiga dengan melakukan kegiatan mengumpulkan informasi dalam bentuk eksperimen dengan dipandu oleh petunjuk kerja, hal ini tentu melatih kemandirian peserta didik. 
Kemudian diberikan soal-soal untuk kegiatan menalar atau mengasosiasi dan dilanjutkan dengan kegiatan menarik kesimpulan dari hasil pengamatan dan studi literatur yang telah dilakukan dan terdapat kegiatan mengkomunikasikan hasil pengamatan di depan kelas. Komponen pembelajaran berbasis pendekatan ilmiah dalam LKPD diperoleh persentase $96,5 \%$ dengan kriteria sangat baik karena memuat langkah pendekatan ilmiah melalui kegiatan mengamati, menanya, mengumpulkan informasi/ eksperimen, mengasosiasi, dan mengkomunikasikan. LKPD mampu memandu peserta didik melakukan langkah pendekatan ilmiah. Hal ini sesuai Permendikbud (2013), pembelajaran dengan pendekatan ilmiah adalah proses pembelajaran yang dirancang sedemikian rupa agar peserta didik secara aktif mengkonstruk konsep, hukum atau prinsip melalui tahapan-tahapan mengamati untuk mengindentifikasi atau menemukan masalah, merumuskan masalah, mengajukan atau merumuskan hipotesis, mengumpulkan data dengan berbagai teknik, menganalisis data, menarik kesimpulan dan mengkomunikasikan konsep, hukum atau prinsip yang ditemukan.

Dari hasil penilaian yang dilakukan oleh ketiga guru biologi tersebut yang mengacu pada beberapa indikator yang telah dimuat dalam instrumen angket maka diperoleh persentase $80,21 \%$ dengan kriteria baik. Hasil penilaian dari peserta didik memperoleh persentase $92 \%$ dengan kriteria sangat baik. Penyajian LKPD mudah dipahami karena bahasa yang digunakan dalam instrumen penilaian sesuai dengan tingkat perkembangkan siswa serta kalimat yang digunakan dalam instrumen jelas dan tidak menimbulkan makna ganda. Hal ini sesuai dengan pendapat Trianto (2010) bahwa, bahasa yang digunakan dalam menyusun kalimat dalam instrumen harus jelas, sederhana dan sesuai dengan kemampuan siswa. LKPD dianggap menarik bagi peserta didik karena desain LKPD terlihat bagus dan tidak berlebihan, berisi kegiatan-kegiatan yang memotivasi peserta didik untuk melakukan langkahlangkah pendekatan ilmiah yaitu mengamati, menanya, mengumpulkan informasi, dan mengkomunikasikan dengan struktur yang dapat menarik perhatian siswa. Hal ini sesuai dengan Depdiknas (2004) menyatakan bahwa dalam penyusunan bahan ajar cetak sangat penting memperhatikan stimulant/kemenarikan instrumen dan kemudahan untuk dibaca.

\section{KESIMPULAN}

Dari penelitian yang dilakukan dapat disimpulkan bahwa hasil validasi aspek materi pada lembar kegiatan peserta didik pada materi pokok Eubacteria berbasis pendekatan ilmiah yang dikembangkan oleh validator ahli materi adalah sangat baik $(93,75 \%)$ yaitu, kelayakan penyajian materi memiliki kriteria sangat baik $(87,5 \%)$ dan aspek kebahasaan memiliki kriteria sangat baik (100\%). Hasil validasi aspek pembelajaran pada lembar kegiatan peserta didik pada materi pokok Eubacteria berbasis pendekatan ilmiah yang dikembangkan oleh validator ahli pendidikan memiliki kriteria sangat baik (92\%) yaitu, kelayakan isi memiliki kriteria sangat baik $(87,5 \%)$ dan komponen pembelajaran berbasis pendekatan ilmiah memiliki kriteria sangat baik (96,5\%). Hasil penilaian dan tanggapan guru terhadap lembar kegiatan peserta didik pada materi pokok Eubacteria berbasis pendekatan ilmiah yang dikembangkan memiliki kriteria baik $(80,21 \%)$. Hasil penilaian dan tanggapan peserta didik terhadap lembar kegiatan peserta didik pada materi pokok Eubacteria berbasis pendekatan ilmiah yang dikembangkan memiliki kriteria sangat baik (92\%).

\section{DAFTAR PUSTAKA}

Depdiknas, (2004), Pedoman Penyusunan Skenario Pembelajaran Sekolah Menengah Atas, Direktorat Jenderal Pendidikan Dasar dan Menengah, Jakarta.

Depdiknas, (2006), Standar Isi Kurikulum Tingkat Satuan Pendidikan. Dapertemen Pendidikan Nasional, Jakarta.

Devi, K.P., (2009), Keterampilan Proses dalam Pembelajaran IPA, Pusat Pengembangan dan Pemberdayaan Pendidikan dan Tenaga Kependidikan Ilmu Pengetahuan Alam.

Kariem, F., Elvyanti, S., Gunawan, Mulyana. (2013). Pengembangan Bahan Ajar Tik SMP Mengacu 
Pada Pembeljaran Berbasis Proyek. Invotec, 9 (2):117-128

Karmana, Oman, (2013), Biologi Kelas X SMA/MA, Grafindo, Jakarta.

Komalasari, K., (2011), Pengembangan Kontekstual Konsep dan Aplikasi. PT Refika Aditama, Bandung.

Mei, F, (2014), Studi Kasus Penerapan Pendekatan Saintifik Pada Guru-Guru di SMA N 1 Bawang (Studi Pada Tahun Ajaran 2013/2014). Economic Education Analysis Journal 3 (3) 2014.

Nurhayati, dkk., 2013, Biologi Kelas X SMA/MA, Yrama Widya, Jakarta.

Pitoyo, dkk., 2013, Biologi Kelas X SMA/MA, Masmedia, Jakarta.

Prawirohartono, dkk., 2013, Biologi Kelas X SMA/MA, Bailmu, Jakarta.

Surachman., Yuni, W., Suhardi. (2014). Implementasi Scientific Procces Pada Mata Pelajaran Biologi di MA Kotamadya Jogjakarta. Jurnal Pendidikan Matematika dan Sains Tahun II, No2, Desember 2014.

Trianto, (2010), Model Pembelajaran Terpadu Konsep, Strategi, dan Implementasinya dalam Kurikulum Tingkat Satuan Pendidikan (KTSP), Bumi Aksara, Jakarta.

Utari, Dwi, (2017), The Implementation of Scientific Approach in Biology Subject in X and XI Grade at Madrasah Aliyah Negeri (MAN) 1 Medan Academic Year 2016/2017, Laporan Hasil Penelitian, FMIPA Universitas Negeri Medan. 